\title{
Evaluation of Prognostic Factors and Middle Ear Risk Index in Type 1 Tympanoplasty
}

\author{
Asmaa Nabil Mohamed, Ahmed Aboulwafa Abdul Jaleel, Mohamed Modather Abd EINaem* \\ Department of Otorhinolaryngology ENT, Faculty of Medicine, Assiut University, Egypt \\ *Corresponding author: Mohamed Modather, Mobile: (+20) 01061577266, E-Mail: m.aboshanif@aun.edu.eg
}

\begin{abstract}
Background: Chronic suppurative otitis media (CSOM) is a long-standing infection of middle ear cleft, characterized by ear discharge and permanent perforation of tympanic membrane. Surgical treatment of CSOM is still controversial. Recently many studies have been undertaken to evaluate the prognostic impact of various factors on the outcomes of tympanoplasty. Nonetheless, only few studies have assessed the clinical preoperative assessment method that allows for tympanoplasty outcome to be predicted.
\end{abstract}

Objective: To examine the role of the prognostic factors and middle ear risk index on the success of tympanoplasty.

Patients and methods: The medical records of 100 patients who underwent type 1 tympanoplasty between 2018 and 2020 were prospectively reviewed. Prognostic factors such as age, sex, presence of systemic diseases, location and size of perforation, duration of dry period, presence of myringosclerosis, presence of septal and conchal pathology, operation type, and status of the opposite ear were evaluated. Middle ear risk index (MERI) was calculated and its correlation with the rate of success of surgery was evaluated.

Results: It was noticed that experience of surgeon more than 5 years, absence of comorbidities and low middle ear risk score were significant predictors for success of tympanoplasty type 1 ( $\mathrm{P}<0.001, \mathrm{P}<0.001, \mathrm{P}<0.001$ respectively).

Conclusion: We found that younger age, female gender, no comorbidities, and higher surgeon experience were associated with better outcome. In addition, patients with mild MERI score showed higher rate of success for tympanoplasty. The surgeon experience and MERI were independent predictors of successful procedure.

Keywords: Factors and Middle Ear Risk Index, Type 1 Tympanoplasty, CSOM.

\section{INTRODUCTION}

Chronic suppurative otitis media (CSOM) is defined as a perforated tympanic membrane with persistent drainage from the middle ear for more than 2-6 weeks ${ }^{(\mathbf{1})}$. The goal of the surgical procedure is not only to close the perforation but also to improve hearing. The success of the operation depends on the ability to eradicate disease from the middle ear ${ }^{(2)}$.

Tympanoplasty is a safe and effective outpatient procedure used to both eradicate disease from the middle ear and restore hearing and middle ear function. A number of surgical approaches and grafting techniques are available for use by the surgeon $(3,4)$. Although, most perforations heal spontaneously, those that persist after dry ear precautions, ototopical drops, or myringoplasty should be considered for surgical repair ${ }^{(5)}$. Tympanoplasty depends to a large extent on the severity of disease present in the middle ear preoperatively. Various grading systems were developed for this such as Belluci grading, Wullstein and Austin five part system, SPITE system of Black ${ }^{(6)}$, Kartush's intrinsic and extrinsic factors ${ }^{(7)}$.

The Middle Ear Risk Index developed by Becvarovski and Kartush combines these factors in the middle ear into a numerical value to assess the prognosis of tympanoplasty ${ }^{(8)}$. Each patient is assigned a numerical score based on the risk factors. The total score is $12^{\left({ }^{(9)}\right.}$. Based on MERI score, the patients are classified as mild disease (1-3), moderate disease (4-6) and severe disease (7- 12). It was modified in 2001. Smoking was added as a risk factor $^{(8)}$.

The MERI combines the known preoperative and intraoperative risk factors for tympanoplasty prognosis into a numeric value. Pinar et al. ${ }^{(10)}$ in their study to examine the role of the prognostic factors and middle ear risk index on the success of tympanoplasty found that the overall success rate was $74.4 \%$. They concluded that the size of the perforation $(<50 \%)$, healthy opposite ear, absence of myringosclerosis, more than 3 months dry period, and low middle ear risk index were found to be significant independent prognostic factors ${ }^{(\mathbf{1 0})}$. Age is one of the prognostic factors. In general, the success of pediatric tympanoplasty is slightly lower than in adults. This has been traditionally attributed to the fact that children have a higher incidence of Eustachian tube dysfunction On the other hand, some authors concluded that patient' age did not influence the surgical success of tympanoplasty ${ }^{(\mathbf{1 1})}$.

Dangol and Shrivastav ${ }^{(12)}$ studied the effect of prognostic factors like size, site of perforation, status of operating ear, approach, status of contralateral ear, experience of surgeon, primary or revision myringoplasty, and smoking in graft uptake in evaluating the hearing results after myringoplasty.

This article is an open access article distributed under the terms and conditions of the Creative Commons Attribution (CC BY-SA) license (http://creativecommons.org/licenses/by/4.0/) 
They concluded that diseased contralateral ear was a statistically significant poor prognostic factor for successful myringoplasty. Other factors such as site and size of perforation, smoking status, revision surgery, status of middle ear, experience of surgeon, and surgical approach were not statistically significant prognostic factors for successful myringoplasty ${ }^{(\mathbf{1 2})}$.

The aim of the present study was to examine the role of the prognostic factors and middle ear risk index on the success of tympanoplasty.

\section{PATIENTS AND METHODS}

This study was conducted in the ENT Department of Assiut University Hospital. 100 patients with chronic suppurative otitis media (CSOM) planned for type 1 tympanoplasty with the age range 18-60 years were included.

They underwent tympanoplasty operations between May 2018 and May 2020 and were reviewed in this study. The patients ranged in age from 16 to 58 years. Patients younger than 16 years old were analyzed in the pediatric age group.

The mean follow-up of patients was 11.8 months (ranged from 6 months to 3 years). Each patient underwent audiologic evaluation from $250 \mathrm{~Hz}$ to $8 \mathrm{kHz}$ preoperatively. Hearing results were based on the most recent audiogram available at 6 months postoperatively. The patients were followed up at three months and six months postoperatively. An intact graft in proper position and aerated middle ear at the end of six months was considered a success. Variables such as age, sex, presence of systemic diseases (diabetes mellitus and hypertension), location and size of the perforation, status of the opposite ear, duration of the dry period, presence of myringosclerosis at admission, presence of nasal moderate septal and inferior conchal pathology (nasal septum deviation and hypertrophy of inferior turbinates), type of operation and risk of the MERI were evaluated (we used the MERI in our study). Patients with the severe septal deviation and inferior turbinates hypertrophy, otorrhea, previous ear surgery on the same ear, cholesteatoma, and deceased to follow-up were excluded from the study.

A detailed history of potential prognostic factors such as age, sex, presence of systemic diseases, duration of dry period, and status of the opposite ear was taken. Otoscopic examination was done to assess the size and site of perforation, and to exclude the presence of granulation tissue and cholesteatoma.

Examination of nose, paranasal sinuses and throat was done to rule out septic foci and to assess presence or absence of septal and conchal pathology and state of the opposite ear. Basic investigations such as CBC and PTA were done. In all patients, underlay surgical technique was used for type 1 tympanoplasty with differences in the grafted material in all patients. All patients underwent general anesthesia and then tympanoplasty type 1 was done through PAI periauricular incision. The initial steps of fascia harvest, perforation edge preparation, and tympanomeatal flap elevation were done. Type 1 tympanoplasty technique was performed. Temporalis fascia graft and cartilage graft or combination of both grafts was used without mastiodectomy. The underlay tympanoplasty technique was done.

All patients were evaluated according to Middle ear risk index (MERI), which includes 5 categories: MERI $0=$ Normal; MERI 1-3 = Mild disease; MERI 4-6 = Moderate disease; MERI 7-12 = Severe disease. Each risk parameter took a numerical value and patients' score was categorized into three categories as follows: Mild (0-3).Moderate (4$6)$.Severe $(\geq 7)$. The patients were evaluated in 3 month and 6-month follow-up visits and underwent clinical examination and pure tone audiometry. An intact graft in the right place, well-aerated middle ear, and restored middle ear function at the end of the third month of follow-up indicated the success of the tympanoplasty.

\section{Ethical approval:}

The study protocol was reviewed by the Scientific and Ethical committee of the Faculty of Medicine, Assiut University, and ethical approval was obtained. Informed consent form was a permanent part of the participants study records and was maintained in the same manner as other records.

Confidentiality: The confidentiality of all participants admitted to this study was protected to the fullest extent possible. The study participants was not identified by name in any report or publication resulting from data collected in this study.

\section{Statistical analysis}

Data were collected and analyzed using SPSS (Statistical Package for the Social Science, version 20, IBM, and Armonk, New York). Continuous data were expressed in form of mean $\pm \mathrm{SD}$ or median (range) while nominal data was expressed in form of frequency (percentage). Chi square test was used to compare the nominal data of different groups in the study, while student t-test was used to compare mean of different two groups. Multivariate regression analysis was used to determine the independent predictors for successful tympanoplasty. Level of confidence was kept at $95 \%$ and hence $\mathrm{P}$ value was significant if $\leq 0.05$.

\section{RESULTS}

The current study was performed at the Department of Otolaryngology in Assiut University Hospital. The study was conducted through the period between May 2018 and May 2020 and aimed to evaluate prognostic factors for tympanoplasty. The study included 100 patients underwent tympanoplasty type I where out of them, 76 (76\%) patients showed successful tympanoplasty and 24 (24\%) patients had failed tympanoplasty. There were 30 males and 46 females. The ages ranged between 16 to 58 years. 
Table (1): Age, sex and comorbidities in patients based on outcome of tympanoplasty

\begin{tabular}{|c|c|c|c|}
\hline & \multicolumn{2}{|c|}{$\begin{array}{c}\text { Outcome of } \\
\text { tympanoplasty }\end{array}$} & \multirow{2}{*}{$\begin{array}{l}P \\
\text { value }\end{array}$} \\
\hline & $\begin{array}{c}\text { Successful } \\
(n=76)\end{array}$ & $\begin{array}{l}\text { Failed }(n= \\
24)\end{array}$ & \\
\hline $\begin{array}{l}\text { Age (years) } \\
\text { Mean } \pm \text { SD } \\
\text { Range }\end{array}$ & $\begin{array}{c}32.44 \pm 9.97 \\
17-56\end{array}$ & $\begin{array}{c}38.25 \pm \\
11.67 \\
20-70\end{array}$ & $\begin{array}{c}< \\
0.001\end{array}$ \\
\hline $\begin{array}{l}\text { Sex: } \\
\text { Male } \\
\text { Female }\end{array}$ & $\begin{array}{l}30(39.5 \%) \\
46(60.5 \%)\end{array}$ & $\begin{array}{c}16(66.7 \%) \\
8(33.3 \%)\end{array}$ & 0.01 \\
\hline $\begin{array}{l}\text { Comorbidities: } \\
\text { None } \\
\text { Diabetes } \\
\text { mellitus } \\
\text { Hypertension } \\
\text { Both }\end{array}$ & $\begin{array}{c}58(76.3 \%) \\
7(9.2 \%) \\
3(3.9 \%) \\
8(10.5 \%)\end{array}$ & $\begin{array}{c}11(45.8 \%) \\
2(8.3 \%) \\
2(8.3 \%) \\
9(37.5 \%)\end{array}$ & 0.01 \\
\hline
\end{tabular}

Out of those patients with successful tympanoplasty, 15 (19.7\%), 43 (56.6\%), and 18 (23.7\%) patients underwent cartilage tympanoplasty, temporalis fascia graft and combined respectively, while out of those with failed tympanoplasty; 8 $(33.3 \%), 11(45.8 \%)$ and $5(20.8 \%)$ patients underwent the same procedures, respectively with insignificant difference between both groups as regarding type of graft $(P=0.38)$. Duration of surgeon experience exceeded five years duration in majority (79\%) of patients with successful tympanoplasty while it was less than five years duration in majority $(62.5 \%)$ of patients with failed tympanoplasty with significant difference between both groups $(P=0.02)$ (Table 2).

Table (2): Type of graft and duration of surgeon experience among patients based on outcome of tympanoplasty

\begin{tabular}{|c|c|c|c|}
\hline & \multicolumn{2}{|c|}{$\begin{array}{c}\text { Outcome of } \\
\text { tympanoplasty }\end{array}$} & \multirow[t]{2}{*}{$\begin{array}{c}P \\
\text { value }\end{array}$} \\
\hline & $\begin{array}{l}\text { Successful } \\
(n=76)\end{array}$ & $\begin{array}{l}\text { Failed }(n= \\
24)\end{array}$ & \\
\hline $\begin{array}{l}\text { Type of graft } \\
\text { Cartilage } \\
\text { tympanoplasty } \\
\text { Temporalis } \\
\text { fascia graft } \\
\text { Combined graft }\end{array}$ & $\begin{array}{l}15(19.7 \%) \\
43(56.6 \%) \\
18(23.7 \%)\end{array}$ & $\begin{array}{c}8(33.3 \%) \\
11(45.8 \%) \\
5(20.8 \%)\end{array}$ & 0.38 \\
\hline $\begin{array}{l}\text { Surgeon } \\
\text { experience } \\
<5 \text { years } \\
>5 \text { years }\end{array}$ & $\begin{array}{l}16(21 \%) \\
60(79 \%)\end{array}$ & $\begin{array}{c}15(62.5 \%) \\
9(37.5 \%)\end{array}$ & 0.02 \\
\hline
\end{tabular}

insignificant differences regarding location of perforation $(P=0.34)$, size of perforation $(P=0.25)$ and duration of dry period $(P=0.08)$. Majority $(73.7 \%$ of successful group and $87.5 \%$ of failed group) of patients in both groups had subtotal perforation. Size of perforation was between $50 \%$ and $75 \%$ of both groups. Three patients in each group had perforation size exceeded $75 \%$ while perforation reached up to $50 \%$ in $16(21.1 \%)$ of successful group and $6(25 \%)$ patients of failed group. It was noticed that only one patient in each group had wet perforation while majority (75\% of successful group and $91.7 \%$ of failed group) of both groups had dry period below three months. Eighteen patients $(23.7 \%)$ of the successful group and only one patient from the failed group had dray perforation for more than three months.

Normal other ear was presented in majority of cases in both groups $(82.9 \%$ with successful tympanoplasty and $79.2 \%$ of failed tympanoplasty; $\mathrm{P}=$ $0.44)$. Twelve $(15.8 \%)$ patients with successful tympanoplasty and $5(20.8 \%)$ patients with failed tympanoplasty had myringosclerosis $(\mathrm{P}=0.38)$. It was noticed that majority of patients in both groups had no associated pathology. Deviated septum, allergic rhinitis and hypertrophied turbinate were presented in $3(3.9 \%), 3(3.9 \%)$, and $4(5.3 \%)$ patients with successful tympanoplasty and $2(8.3 \%), 1(4.2 \%)$, and $1(4.2 \%)$ patients with failed tympanoplasty, respectively (Table 3 ).

Table (3): Characteristics of perforation and presence of associated pathology among the enrolled patients

\begin{tabular}{|c|c|c|c|}
\hline & \multicolumn{2}{|c|}{$\begin{array}{c}\text { Outcome of } \\
\text { tympanoplasty }\end{array}$} & \multirow[t]{2}{*}{$\begin{array}{c}P \\
\text { value }\end{array}$} \\
\hline & $\begin{array}{c}\text { Successful } \\
(n=76)\end{array}$ & $\begin{array}{l}\text { Failed } \\
(n=24)\end{array}$ & \\
\hline $\begin{array}{l}\text { Location of } \\
\text { perforation } \\
\text { Antero-inferior } \\
\text { Postero-inferior } \\
\text { Subtotal } \\
\end{array}$ & $\begin{array}{c}4(5.3 \%) \\
16(21.1 \%) \\
56(73.7 \%)\end{array}$ & $\begin{array}{c}1(4.2 \%) \\
2(8.3 \%) \\
21 \\
(87.5 \%)\end{array}$ & 0.34 \\
\hline $\begin{array}{l}\text { Size of } \\
\text { perforation } \\
\text { Up to } 50 \% \\
50-75 \% \\
\text { More than } 75 \%\end{array}$ & $\begin{array}{c}16(21.1 \%) \\
57(75 \%) \\
3(3.9 \%)\end{array}$ & $\begin{array}{c}6(25 \%) \\
15 \\
(62.5 \%) \\
3(12.5 \%)\end{array}$ & 0.25 \\
\hline $\begin{array}{l}\text { Duration of dray } \\
\text { period } \\
\text { Above } 3 \text { months } \\
\text { Below } 3 \text { months } \\
\text { Wet perforation }\end{array}$ & $\begin{array}{c}18(23.7 \%) \\
57(75 \%) \\
1(1.3 \%)\end{array}$ & $\begin{array}{c}1(4.2 \%) \\
22 \\
(91.7 \%) \\
1(4.2 \%)\end{array}$ & 0.08 \\
\hline \multicolumn{4}{|c|}{ Presence of associated pathology: } \\
\hline $\begin{array}{l}\text { State of other ear } \\
\text { Normal } \\
\text { Abnormal }\end{array}$ & $\begin{array}{l}63(82.9 \%) \\
13(17.1 \%)\end{array}$ & $\begin{array}{c}19 \\
(79.2 \%) \\
5(20.8 \%)\end{array}$ & 0.44 \\
\hline $\begin{array}{l}\text { Presence of } \\
\text { myringosclerosis }\end{array}$ & $12(15.8 \%)$ & $5(20.8 \%)$ & 0.38 \\
\hline $\begin{array}{l}\text { Septal and } \\
\text { conchal } \\
\text { pathology } \\
\text { None } \\
\text { Deviated septum } \\
\text { Allergic rhinitis } \\
\text { Hypertrophied } \\
\text { turbinate }\end{array}$ & $\begin{array}{c}66(86.8 \%) \\
3(3.9 \%) \\
3(3.9 \%) \\
4(5.3 \%)\end{array}$ & $\begin{array}{c}20 \\
(83.3 \%) \\
2(8.3 \%) \\
1(4.2 \%) \\
1(4.2 \%)\end{array}$ & 0.85 \\
\hline
\end{tabular}

It was noticed that majority of patients in both groups had air bone gap (25-30) with insignificant difference between both groups $(P=0.46)$. It was noticed that middle ear risk score was either mild 
(47.4\%) or moderate $(52.6 \%)$ among patients with successful tympanoplasty and none of them had severe score. Out of failed group, 3 (12.5\%), 12 (50\%), and 9 (37.5\%) patients had mild, moderate and severe score, respectively (Table 4).

Table (4): Pure tone audiometry and middle ear risk score among enrolled patients

\begin{tabular}{|c|c|c|c|}
\hline & \multicolumn{2}{|c|}{$\begin{array}{c}\text { Outcome of } \\
\text { tympanoplasty }\end{array}$} & \multirow[t]{2}{*}{$\begin{array}{c}P \\
\text { value }\end{array}$} \\
\hline & $\begin{array}{c}\text { Successful } \\
(n=76)\end{array}$ & $\begin{array}{l}\text { Failed }(n= \\
\text { 24) }\end{array}$ & \\
\hline $\begin{array}{l}\text { Baseline PTA } \\
\text { ABG }(15-20) \\
\text { ABG }(20-25) \\
\text { ABG }(25-30) \\
\text { ABG }(30-35)\end{array}$ & $\begin{array}{c}5(6.6 \%) \\
25(32.9 \%) \\
40(52.6 \%) \\
6(7.9 \%)\end{array}$ & $\begin{array}{c}1(4.2 \%) \\
5(20.8 \%) \\
14(58.3 \%) \\
4(16.7 \%)\end{array}$ & 0.46 \\
\hline $\begin{array}{l}\text { Middle ear } \\
\text { risk } \\
\text { Mild } \\
\text { Moderate } \\
\text { Severe }\end{array}$ & $\begin{array}{c}36(47.4 \%) \\
40(52.6 \%) \\
0\end{array}$ & $\begin{array}{l}3(12.5 \%) \\
12(50 \%) \\
9(37.5 \%)\end{array}$ & $\begin{array}{r}< \\
0.001\end{array}$ \\
\hline
\end{tabular}

Data were expressed as frequency (percentage). $P$ value was significant if $\leq 0.05$.PTA: pure tone audiogram; ABG: air bone gap.

It was noticed that the graft was broken after three months and broken with anterior perforation after six months in all patients with failed tympanoplasty. In case of successful group, the graft was intact in 33 (47\%) patients and taken with residual perforation in $29(41.4 \%)$ patients. The graft was broken in only eight patients after three months. After six months, graft was intact in $52(68.4 \%)$ patients with successful tympanoplasty while the graft was broken with central perforation in $18(23.7 \%)$ and anterior perforation in 6 (7.9\%) (Table 5).

Table (5): Graft status after three and six months in both groups

\begin{tabular}{|c|c|c|c|}
\hline & \multicolumn{2}{|c|}{$\begin{array}{c}\text { Outcome of } \\
\text { tympanoplasty }\end{array}$} & \multirow{2}{*}{$\begin{array}{l}P \\
\text { value }\end{array}$} \\
\hline & $\begin{array}{c}\text { Successful } \\
(n=76)\end{array}$ & $\begin{array}{c}\text { Failed }(n= \\
24)\end{array}$ & \\
\hline $\begin{array}{l}\text { After three months } \\
\text { Intact } \\
\text { Taken with } \\
\text { residual } \\
\text { perforation } \\
\text { Broken }\end{array}$ & \begin{tabular}{|c}
33 \\
$(47.1 \%)$ \\
29 \\
$(41.4 \%)$ \\
$8(11.4 \%)$ \\
\end{tabular} & $\begin{array}{c}0 \\
0 \\
24(100 \%)\end{array}$ & $\begin{array}{c}< \\
0.001\end{array}$ \\
\hline \begin{tabular}{|l|} 
After six months \\
Intact \\
Broken with \\
central perforation \\
Broken with \\
anterior \\
perforation
\end{tabular} & $\begin{array}{c}52 \\
(68.4 \%) \\
18 \\
(23.7 \%) \\
6(7.9 \%)\end{array}$ & $\begin{array}{c}0 \\
0 \\
24(100 \%)\end{array}$ & $\begin{array}{c}< \\
0.001\end{array}$ \\
\hline
\end{tabular}

None of patients with failed tympanoplasty had closed ABG either after three or six months. It was noticed that $3(12.5 \%), 2(8.3 \%)$ and $19(79.2 \%)$ patients had ABG (5-10), ABG (10-15) and ABG (>
15), respectively after three months. After six months, all patients with failed tympanoplasty had ABG $>15$. It was noticed that 45 (59.2\%), and $52(68.4 \%)$ patients with successful tympanoplasty had closed $A B G$ after three and six months, respectively. ABG (5-10), ABG $(10-15)$, and $\mathrm{ABG}(>15)$ were presented in 20 $(26.3 \%), 7(9.2 \%)$, and $4(5.3 \%)$ patients with successful group after three months, respectively while $4(5.3 \%), 11(14.5 \%)$, and $9(11.8 \%)$ of those patients had ABG (5-10), ABG (10-15), and ABG (> 15) after six months, respectively (Table 6).

Table (6): Pure tone audiogram after three and six months among enrolled patients

\begin{tabular}{|l|c|c|c|}
\hline \multirow{2}{*}{} & \multicolumn{2}{|c|}{$\begin{array}{c}\text { Outcome of } \\
\text { tympanoplasty }\end{array}$} & \multirow{2}{*}{$\boldsymbol{P}$ value } \\
\cline { 2 - 3 } & $\begin{array}{c}\text { Successful } \\
(\mathbf{n = 7 6})\end{array}$ & $\begin{array}{c}\text { Failed } \\
(\mathbf{n = 2 4 )}\end{array}$ & \\
\hline After three months & & & \\
ABG (closed) & $45(59.2 \%)$ & 0 & \\
ABG (5-10) & $20(26.3 \%)$ & $3(12.5 \%)$ & $<0.001$ \\
ABG (10-15) & $7(9.2 \%)$ & $2(8.3 \%)$ & \\
ABG (> 15) & $4(5.3 \%)$ & 19 & \\
& & $(79.2 \%)$ & \\
\hline After six months & $52(68.4 \%)$ & 0 & \\
ABG (closed) & $4(5.3 \%)$ & 0 & $<0.001$ \\
ABG (5-10) & $11(14.5 \%)$ & 0 & \\
ABG (10-15) & $9(11.8 \%)$ & $24(100 \%)$ & \\
ABG (> 15) & & & \\
\hline
\end{tabular}

Based on the current study, it was noticed that predictors for successful tympanoplasty were experience of surgeon more than 5 years (odd's ratio= $0.22,95 \%$ confidence interval $=0.22-0.99 ; P<0.001$ ), absence of comorbidities (odd's ratio $=0.33,95 \%$ confidence interval $=0.10-0.90 ; P<0.001)$ and low middle ear risk score (odd's ratio $=0.76,95 \%$ confidence interval=0.22-0.99; $P<0.001)$ (Table 7).

Table (7): Predictors of successful tympanoplasty among enrolled patients

\begin{tabular}{|l|c|c|c|c|}
\hline \multirow{2}{*}{} & \multicolumn{2}{|l|}{ Univariate analysis } & \multicolumn{2}{c|}{$\begin{array}{c}\text { Multivariate } \\
\text { analysis }\end{array}$} \\
\cline { 2 - 5 } & $\begin{array}{c}\text { OR } \\
(\mathbf{9 5 \%} \text { CI) }\end{array}$ & $\begin{array}{c}\boldsymbol{P} \\
\text { value }\end{array}$ & $\begin{array}{c}\text { OR } \\
(\mathbf{9 5 \%} \text { CI })\end{array}$ & $\begin{array}{c}\boldsymbol{P} \\
\text { value }\end{array}$ \\
\hline Old age & $\begin{array}{c}\text { (9.34 (0.11- } \\
1.23)\end{array}$ & 0.04 & & \\
\hline Female sex & $0.18(0.10-$ & 0.04 & & \\
& $0.45)$ & & & \\
\hline Experience & $0.91(0.22-$ & 0.01 & 0.22 & $<$ \\
& $0.99)$ & & $(0.10-$ & 0.001 \\
& & & $0.50)$ & \\
\hline No & 0.45 & 0.02 & 0.33 & $<$ \\
comorbidities & $(0.15-0.56)$ & & $(0.10-$ & 0.001 \\
& & & $0.90)$ & \\
\hline Low middle & 0.91 & 0.01 & 0.76 & $<$ \\
ear risk & $(0.22-0.98)$ & & $(0.22-$ & 0.001 \\
& & & $0.89)$ & \\
\hline
\end{tabular}

$P$ value was significant if $<0.01$. OR: odd's ratio; $\mathbf{C I}$ : confidence interval. 
In the present study, the mean age of the included patients was $33.84 \pm 10.64$ years old and 52\% of them were females. On the other hand, diabetes mellitus (DM) and hypertension (HTN) were presented in $9(9 \%)$ and $5(5 \%)$ patients, respectively. Both DM and HTN were presented in 17 (17\%) patients. In line with our findings, Nemati et al. ${ }^{(13)}$ conducted an observational study with 62 adults with established CSOM. Of the 62 patients, $60 \%$ females. The mean age of patients was $37.1 \pm 14.3$ years old. Likewise, Nshimirimana et al. (14) conducted a cross-sectional survey at a tertiary teaching hospital in Rwanda. A questionnaire was used to collect data of patients diagnosed with CSOM who attended ENT Department during the study period. This study enrolled 109 patients, of whom 59\% were females.

Concerning the success rate of tympanoplasty type I, there were $76(76 \%)$ patients with successful tympanoplasty and $24(24 \%)$ patients had failed tympanoplasty. Such findings are similar to Fadl ${ }^{(15)}$ study, who carried out a retrospective study from the records pertaining to all patients who had tympanoplasty type-1 at King Fahd Specialized Hospital, Buraidah, Al-Qassim, Kingdom of Saudi Arabia between April 1995 and April 2000. The overall success rate was $80 \%$. Similarly, Tan et al. (16) conducted a systematic review to determine which independent variables influence the efficacy of type I tympanoplasty in adult and pediatric populations. Of 4,698 abstracts reviewed, 214 studies involving 26,097 patients met our inclusion criteria and contributed to meta-analysis. The weighted average success rate of tympanic closure was $86.6 \%$.

In terms of the association between the outcomes of tympanoplasty and demographic characteristics, our results showed that the mean age of patients with successful tympanoplasty was significantly lower than those with failed tympanoplasty $(32.44 \pm 9.97$ vs. $38.25 \pm 11.67$ years; $P<0.001)$. It was noticed that majority $(60.5 \%)$ of successful tympanoplasty were females while majority (66.7\%) of failed tympanoplasty were males $(P=0.01)$. It was noticed that morbidities were associated with failed tympanoplasty. In multivariate analysis, the presence of comorbidities was a significant predictor of successful procedure. In agreement with our findings, Emir et al. ${ }^{(17)}$ aimed to identify the factors that could influence the success rate of type 1 tympanoplasty in a tertiary care centre where both residents and senior surgeons perform this operation. Six hundred and seven patients who had been performed type 1 tympanoplasty as a primary otologic surgery were retrospectively chart reviewed. The male gender and younger age were stated as prognostic factors. Likewise, Boronat-Echeverría et al. (18) included 48 patients, who had persistent perforation of the tympanic membrane, and had undergone tympanoplasty (January 2005-June 2008). Younger age was stated as a good prognostic factor. On the contrary, Singh et al. ${ }^{(19)}$ conducted a prospective study to evaluate the success rate of tympanoplasty type I and analyze the factors suggested to influence the outcome of the said surgery. Statistically, age did not influence tympanoplasty type I outcomes. The exact cause of such difference may be attributed to different epidemiological characteristics, different sample sizes, and surgeons' experience.

Several types of materials have been used to reconstruct the tympanic membrane. Among the autologous grafts, the following can be mentioned: temporalis fascia, fascia lata, periosteum, perichondrium, cartilage with and without perichondrium, veins, fatty tissue, and skin. Several allografts are mentioned in the literature and include dura mater, pericardium, temporalis fascia, amniotic membrane, skin, cornea, peritoneum, veins, and aortic valve. Recently, alloplastic grafts such as paper, absorbable gelatin sponge, and acellular dermal matrix have also been used ${ }^{(20)}$.

In the present study, we found no statistically significant association between type of graft and success rate. In agreement with our findings, Lee $\boldsymbol{e t}$ al. (21), in a retrospective analysis of 40 patients with chronic otitis media and granulation tissue in the middle ear, compared the anatomical and audiological results of type I tympanoplasty using fascia temporalis, cartilage tissue, and cartilage palisade. No statistically significant differences were observed between the three groups regarding the success rate and the closure of tympanic membrane perforations. In a systematic literature review, Mohamad et al. (22) found that tympanoplasty using fascia temporalis and cartilage grafts showed similar and comparable success rate and functional outcomes (hearing improvement).

Type 1 tympanoplasty has generally been considered an "easy" operation. In training and research clinics, where both residents and senior surgeons perform this kind of operations, it is usually the first middle ear operation allowed to be performed by residents in training ${ }^{(17)}$.

In the present study, we found that the duration of surgeon experience exceeded five years duration in majority (79\%) of patients with successful tympanoplasty while it was less than five years duration in majority $(62.5 \%)$ of patients with failed tympanoplasty with significant difference between both groups $(P=0.02)$. In multivariate analysis, the experience of surgeon more than 5 years was predictor of successful procedure (odd's ratio $=0.22,95 \%$ confidence interval $=0.22-0.99 ; \mathrm{P}<0.001)$. Similar to our findings, Emir et al. (17) reported that the experience of the surgeon was stated as good prognostic factor for type 1 tympanoplasty. In addition, Bedri et al. ${ }^{(23)}$ conducted a retrospective review of the medical records tallied preoperative risk factors and perforation sizes for four consecutive 100- blocks of double- layer tympanoplasties. The authors reported that the experience of the surgeon was stated as good prognostic factor for type 1 
tympanoplasty. On the contrary, Naderpour et al. (24) carried out a prospective study, based on the results of tympanoplasty with temporal graft fascia in 60 patients in the ENT department of the Medical Science University of Tabriz. The rate of surgical success, integration of the graft, was $93.3 \%$. The authors did not find that surgical experience to be statistically significant to affect surgical outcome.

\section{Conclusion:}

In our study, we found that younger age, female gender, no comorbidities, and higher surgeon experience were associated with better outcome. In addition, patients with mild MERI score showed higher rate of succeeded for tympanoplasty than patients with moderate and severe MERI score. The surgeon experience and MERI were independent predictors of successful procedure. We believe that having a tool for prediction of outcomes of tympanoplasty will be useful for the otorhinolaryngologist, since it is a practical instrument. Nevertheless, further studies with rigorous design, large sample size and multiregional cooperation are required.

\section{REFERENCES}

1. Neeff M, Biswas K, Hoggard M et al. (2016): Molecular Microbiological Profile of Chronic Suppurative Otitis Media. J Clin Microbiol., 54 (10): 2538-46.

2. Neudert M, Zahnert T (2017): Tympanoplasty-news and new perspectives. GMS Current Topics in Otorhinolaryngology, Head and Neck Surgery, 16: 1-21.

3. Mittal R, Lisi C, Gerring $\mathrm{R}$ et al. (2015): Current concepts in the pathogenesis and treatment of chronic suppurative otitis media. Journal of Medical Microbiology, 64 (Pt 10): 1103-8.

4. Isaacson G, Melaku A (2016): Results of pediatric tympanoplasty on short- term surgical missions. The Laryngoscope, 126 (6): 1464-1469.

5. Nambiar S (2017): Tympanoplasty type I evaluation of the surgical results and its impact as the treatment modality in chronic otitis media. J Evid Based Med Health, 4 (58): 3507-3511.

6. Black B (1992): Ossiculoplasty prognosis: the SPITE method of assessment. American Journal of Otology NewYork, 13: 544-544.

7. Kartush J (1994): Ossicular chain reconstruction. Capitulum to malleus. Otolaryngologic Clinics of North America, 27 (4): 689-715.

8. Becvarovski Z, Kartush J (2001): Smoking and tympanoplasty: implications for prognosis and the Middle Ear Risk Index (MERI): The Laryngoscope, 111 (10): 1806-1811.

9. Gitanjali $\mathbf{N}$ (2016): The role of middle ear risk index on the outcome of tympanoplasty (Doctoral dissertation,
Thanjavur Medical College, Thanjavur). http://repositorytnmgrmu.ac.in/2433/1/2204005gitanjaln.pdf

10.Pinar E, Sadullahoglu K, Calli C et al. (2008): Evaluation of prognostic factors and middle ear risk index in tympanoplasty. Otolaryngology-Head and Neck Surgery, 139 (3): 386-390.

11. Yung M, Neumann C, Vowler S (2007): A longitudinal study on pediatric myringoplasty. Otology \& Neurotology, 28 (3): 353-355.

12.Dangol K, Shrivastav R (2017): Study of various prognostic factors affecting successful Myringoplasty in a tertiary care Centre. International Archives of Otorhinolaryngology, 21 (03): 250-254.

13. Nemati S, Jafari S, Shakiba $R$ et al. (2015): Allergic Rhinitis in Adults with Chronic Suppurative Otitis Media. Iranian Journal of Otorhinolaryngology, 27: 261-6.

14. Nshimirimana J, Mukara K (2018): Causes of Delayed Care Seeking for Chronic Suppurative Otitis Media at a Rwandan Tertiary Hospital. International Journal of Otolaryngology, 18: 1-5.

15.Fadl F (2003): Outcome of type-1 tympanoplasty. Saudi Medical Journal, 24: 58-61.

16. Tan H, Santa Maria P, Eikelboom R et al. (2016): Type i Tympanoplasty Meta-Analysis: A Single Variable Analysis. Otology and Neurotology, 37: 838-846.

17. Emir H, Ceylan K, Kizilkaya Z et al. (2007): Success is a matter of experience: Type 1 tympanoplasty - Influencing factors on type 1 tympanoplasty. European Archives of Oto-Rhino-Laryngology, 264: 595-599.

18. Boronat-Echeverría N, Reyes-García E, SevillaDelgado Y et al. (2012): Prognostic factors of successful tympanoplasty in pediatric patients: A cohort study. BMC Pediatrics. Bio Med Central, 12: 67-73.

19. Singh G, Sidhu T, Sharma A et al. (2005): Tympanoplasty type I in children - An evaluative study', in International Journal of Pediatric Otorhinolaryngology. Int J Pediatr Otorhinolaryngol., 8: 1071-1076.

20.de Freitas M, de Oliveira T (2014): The role of different types of grafts in tympanoplasty. Brazilian Journal of Otorhinolaryngology, 80: 275-276.

21. Lee J, Lee S, Nam J et al. (2012): Comparison of different grafting techniques in type i tympanoplasty in cases of significant middle ear granulation. Otology and Neurotology, 4: 586-590.

22. Mohamad S, Khan I, Hussain S (2012): Is cartilage tympanoplasty more effective than fascia tympanoplasty? A systematic review. Otology and Neurotology, 5: 699705 .

23.Bedri E, Worku A, Redleaf M (2019): The effect of surgeon experience on tympanic membrane closure. Laryngoscope Investigative Otolaryngology, 4: 526-531.

24. Naderpour M, Jabbari Moghadam Y, Ghanbarpour E et al. (2016): Evaluation of Factors Affecting the Surgical Outcome in Tympanoplasty. Iranian Journal of Otorhinolaryngology, 28: 99-104. 